\title{
Through the looking glass
}

By Opritsa D. Popa

Bibliographer for Economics,

Russian, and German

Humanities and Social Sciences

University of California, Davis and Sandra J. Lamprecht

Online Search Coordinator

Humanities and Social Sciences

University of California, Davis

\section{A sampling of University of California students' experiences in libraries abroad.}

he University of California's Education Abroad Program (UC-EAP) extends today to 80 institutions in 33 countries. In 1988/89 over 1,000 undergraduates left UC campuses to study abroad. To ensure the quality of the program, EAP requires the following minimum qualifications: a 3.0 cumulative GPA, completion of foreign language courses, where needed, and approval of candidates by a campus selection committee. The reputation of the UC-EAP program is widely recognized: host institutions consider it to be one of the best of its kind and participants compare most favorably with other undergraduates studying abroad. ${ }^{1}$

In the Administrative Review of the Education Abroad Program (1989), the stringent academic standards facing EAP participants abroad were underscored: "University students in most European countries are a highly select group representing the country's best young minds. EAP participants in integrated programs thus face two formidable challenges-matching their skills with those of highly qualified local students in an atmosphere of high academic expectations, and being perceived, for better or for worse, as the best and

${ }^{1}$ A. T. Brugger, et al., An Administrative Review of the Education Abroad Program (Berkeley, Calif.: University of California, Office of the President, 1989), 1. brightest their university, if not their country, has to offer. A student's ability to deal with these challenges can be the determining factor in the success of the EAP experience." It is our conviction that effective use of information sources in host university libraries is one of the contributing factors to academic success.

EAP annually distributes a questionnaire to students who have recently returned from their education abroad experience. While very detailed and carefully crafted, this survey does not solicit detailed information on students' experience in foreign. university libraries. A group of 20 questions, however, requires students to compare various aspects of their academic environment abroad, including libraries, with their UC campus experiences. This comparison is expressed on a scale from one to five, where one is labeled "Much Less Abroad," three is "Same as UC," and five is "Abroad Much More." A table published in Participant Questionnaire: Analysis of Responses ${ }^{3}$ recorded the mean value for each of these 20 academic aspects computed across all respondents.

While most data clustered around three, i.e., the

${ }^{2}$ Brugger, 26.

${ }^{3}$ Jerry S. Carlson and David J. Yachimowics, Participant Questionnaire: Analysis of Responses (Santa Barbara, Calif.: University of California, Education Abroad Program, 1987), 136-137. 
experience abroad was similar to the experience at the UC home campus, two questions received comparatively lower scores: "Availability of Computers Abroad" scored lowest at a 1.48 mean, while "Usefulness of Library Facilities Abroad" scored slightly higher, at 1.78 .

This dissatisfaction of UC students with foreign university libraries prompted us to probe further for data and opinions. To this end a questionnaire was sent to 1,000 1988/89 UC-EAP students, studying in 33 countries. This questionnaire queried students on collection availability, access, library facilities, library hours and services at the foreign university library they were using. The percentage of return (10\%) was not large enough to lend itself to statistical analysis. ${ }^{4}$ Nonetheless, as most responses expressed dissatisfaction with libraries abroad, our results supported the data recorded in the 1987 Participant Questionnaire. ${ }^{5}$ Furthermore, the information collected by our survey identified the areas where foreign library reality fell short of students' expectations and helped explain why service, environment and collections were perceived as less useful than home campus libraries.

\section{Expectations and realities}

The vast majority of responses to our questionnaire were critical of one or more aspects of foreign library organization, facilities, collections, and services. Most EAP students seemed totally unprepared to discover that major differences exist between the UC and foreign libraries in practically every aspect of library life. These differences, discussed in the following sections, prompted reactions ranging from mild irritation to deep frustration and disorientation.

\section{Library hours}

EAP students are accustomed to finding their libraries open from 8:00 a.m. to midnight at least five days per week during the academic year with certain reading rooms remaining open around the clock. EAP participants discovered that such generous hours are scarcely the norm abroad. From a university library in Ghana, a student deplored the fact that the library "does not open on time, and during break the hours are very sporadic." From France, Israel, Japan, Sweden, Australia, Hong

${ }^{4}$ Reasons for this small rate of return included serious delays of the mail while en route to EAP students. Although the questionnaires were mailed with an "air mail" designation in February, many recipients did not receive them until mid-May or June. Our deadline for response was May 1, 1989.

${ }^{5}$ Carlson, 136-137.
Kong, and Ireland, students complained about limited library hours making research difficult to fit into their schedule. According to their responses, with one exception in New Zealand, no foreign library is open after 10:00 p.m., while a great number close their doors by dinner time. During vacations and holidays many libraries remain dark. Furthermore, in Japan, Mexico, Scotland, Norway, Sweden, Spain, and Ireland, students found libraries closed on weekends. In Padua, Italy, most libraries close between 1:00 p.m. and 3:00 p.m., taking the obligatory siesta.

\section{Adequacy of buildings and equipment}

Our questionnaire prompted EAPers to comment on library space, comfort, light, temperature control and noise levels. The majority of students complained about overcrowding in reading areas, lack of comfort in furniture design, and high noise levels. Light and temperature control, however, appeared to be acceptable to most, while photocopying facilities, despite some limitations, seem to be currently the norm in host university libraries. A particularly pleasant study environment mentioned was St. Andrews University Library in Scotland. Its reading room was described as very comfortable and with a magnificent view of the North Sea.

\section{Stacks}

For general collections, UC libraries adhere to an open stacks, self-service policy. Abroad, the great majority of libraries offered direct access to their collections as well. Some libraries, e.g., Ireland, Australia, Costa Rica, and France were reported to have both open and closed stacks. Several European libraries, however, offered solely mediated access to their resources. This policy is dictated by necessity, "since books are often shelved by size and/or chronological order in labyrinthine stacks created wherever space can be found."6 In such cases students complained about unreasonable delays in receiving materials and bemoaned the loss of browsing capabilities.

"The closed stacks are my main source of frustration," wrote a student from Spain, "Just to get books takes at least 45 minutes to $2^{1 / 2} 2$ hours." In France, "you order as many books as you want and can pick them up a few days later. This makes for many library runs!" Closed stacks appeared to be predominant in Ireland, Scotland, Italy, Norway, Sweden, and France.

${ }^{6}$ Joan McConkey, "French University Libraries in 1988," C $\prec R L$ News 49 (December 1988): $739-43$. 


\section{Collections}

In the UC system adequate book budgets have allowed for steady and healthy collection growth. In addition to well-rounded older collections, UC libraries maintain strong current collections of books, journals and magazines, as well as multiple copies of standard works, a mainstay of undergraduate populations.

Foreign university libraries do not necessarily follow the same collecting patterns. For several countries budgeting difficulties affecting libraries have resulted in very selective current acquisitions. Some of the libraries used by EAPers exhibited gaps in current materials. Among these were the libraries in Hong Kong, Japan, Taiwan, Costa Rica, and Ghana where "most publications are pre1976." In Spain students encountered difficulties in finding current information: "Many books are too old and they are not even useful," writes a student from Spain. "As far as future EAP students go-tell them B.Y.O.B. = Bring Your Own Books!"

With regard to student's experiences in England, "the library suffers from severe lack of funds resulting in very few books being added, and often only one copy, even of major works," laments one undergraduate. Libraries, in general, do not seem to acquire multiple copies of requested course materials. This, according to responses, results in many texts being put on reserve or short loan, which is inconvenient due to the limited copying facilities.

Nonetheless, where "treasures" were found, EAPers were not frugal with praise: "Trinity," writes a student from Ireland, "as a copyright deposit library has superlative coverage of British publications (including those U.S. academic publishers who maintain a London presence, like UC Press) and quite good coverage of early (Aldine 15th Century and later) printed editions."

"The Balme Library is a wonderful library for old periodicals," writes a student from Ghana, while another considers Hebrew University Library in Israel as "the best" he has ever used. From a library in Padua, Italy, a student marveled at old manuscript collections.

\section{Collection access}

Access differences can leave students puzzled and disoriented. In France, students searched for "an equivalent to Readers' Guide" and did not have a clue on how to find periodical articles by subject. At a Library in Hong Kong the circulation computer was inaccurate in reporting missing or checked out books. Padua libraries were seen as "chaotic," "very unorganized," and "not well cataloged." "Research in Italy is extremely difficult to do as books are either missing/stolen or too delicate to photocopy. In the rare chance that you find a book to photocopy, you can only photocopy 50 pages. Overall, doing research is a near impossible nightmare for Americans and Italians alike. Computerized searching is unheard of and new acquisitions rare."

From Mexico a student commented that "shelving in call number order is not strictly respected, resulting in many misplaced (i.e. lost) materials."

We were especially interested in knowing whether students found online public access catalogs (OPACS) in libraries abroad and if these systems were "user-friendly." The majority of students did not find online catalogs abroad and some expressed dismay. A student in Israel commented, "If it weren't for the lack of an online user-friendly catalog, my library experiences abroad would have been fulfilled. However, there wasn't such an instrument of efficiency, and I was left not quite satisfied."

OPACS were also not found at EAP host university libraries in France, Italy, Norway, Australia, Hong Kong, and Ireland. In older European libraries, where card catalogs are the only access to the collection, students were amazed to find old handwritten bibliographic entries. Among countries whose collections were available via OPACS, students mentioned NewZealand, England, Scotland, and Japan. However, online catalogs of the UC system were consistently rated superior and more user-friendly than any of their foreign counterparts.

Loan periods for library materials were, in general, adequate. Fines for tardy or lost library materials appear similar to those of the UC system.

\section{Reference help}

Most foreign libraries reportedly offer reference service. We hypothesized that EAP participants would avail themselves of this service. The majority of our respondents confirmed this assumption, and rated these services as satisfactory. However, close to one-third characterized librarians as "insensitive" to their information needs.

Students in Spain expressed the most displeasure with reference librarians. Out of seven surveyed, five students were unhappy with the service received. Librarians seemed not to care: "They can't be fired very easily, so they are as rude as they want to be," was the comment of an unhappy EAP student. Overall, Canadian reference librarians received favorable remarks. However, here too, an EAP student came "across one bad apple."

In their concluding remarks, many EAP participants expressed gratitude to their home UC librarians for being helpful and sensitive to their information needs. 


\section{Orientation tours and information brochures}

Many host libraries did not advertise library orientation tours in a manner that would catch the eye of a foreign student. EAPers in Costa Rica, the Peoples Republic of China, Denmark, France, Israel, Spain, Italy, Japan, Mexico, Norway, Sweden, and Taiwan either responded that they were unaware of any orientation tours or that no tours were available.

A Costa Rica student commented: "Some of the problems I had early on could have been avoided by some kind of library orientation tour." The majority of students in Austria, Canada, England, Germany, Australia, New Zealand, and Scotland, on the other hand, participated in library orientation or at least knew of its existence.

In the UC library system, informational brochures describing library layout, collections, hours or services seem to be much more visible than abroad. Out of 79 responses, 62 students could not find any brochures. No information brochures could be found by EAPers in libraries in Austria, the Peoples Republic of China, Costa Rica, France, Germany, Israel, Spain, Italy, Mexico, Norway, or Taiwan.

EAPers in Canada, England, Australia, Ireland, and New Zealand had the most luck in finding printed guides. This data seems to indicate that EAP students in English-speaking countries found guides while those in foreign-language countries did not. Whether guides in the language of the country were available and not used by foreign students or whether brochures are not a high priority and/or not considered relevant remains an open question.

\section{Online access to remote databases}

The vast majority of students either did not have access to, or know about, online sources via a vendor system such as DIALOG at their host libraries. From a total of 80 responses, only eight students reported such a service. These eight students were studying in England, Denmark, New Zealand, Scotland, or Sweden. No one in this group felt sufficiently inspired by the service to comment either on its merits or its deficiencies.

\section{Concluding remarks}

Responses to our questionnaire support the conclusion that UC students selected for EAP, although academically accomplished, do not seem to adapt quickly to foreign library environments.

At the time of their departure, EAP students lack important information about organizational, operational and collecting differences between the
UC and host libraries abroad. Thus an important component to academic success, access to information, appears to be underutilized.

Frustrations with foreign libraries and false expectations could be greatly minimized if librarians would actively participate in the planning stages of this educational journey. Predeparture activities may include a presentation on conducting research in libraries abroad. On this occasion, differences and potential problems could be outlined.

Obviously, not all problems and difficulties can be solved by educational means. Nevertheless, arming students with specific and directly applicable information on foreign libraries may make their transition easier.

A useful suggestion to traveling scholars advanced by Fagan ${ }^{7}$ could be adapted to the situation of the education abroad participant. Based on detailed questionnaires sent to key host libraries, librarians could develop profiles of foreign information centers used by EAP students. These profiles may list such data as hours and calendar, loan periods, how to obtain a library card, collection access and collecting patterns, special strengths of collections, services, photocopying facilities and a description of the library environment. The library profiles could be maintained as a computer-file and could be updated by requesting periodic revision from host libraries. They could be made available to all interested departing students. Upon their return students could add written comments that would help personalize a library experience and ease their colleagues' entrance into a very different and challenging library world.

${ }^{7}$ Michele L. Fagan, "Practical Aspects of Conducting Research in British Libraries and Archives," RQ 26 (Spring 1987): 371.

\section{Fulbright position in U.K.}

The Fulbright Commission in London has announced an opportunity for a practicing librarian to pursue professional work in the United Kingdom at a degree-awarding institution or major research library. The competitive award is being made available under the Fulbright Scholar Program to allow librarians to enhance cross-cultural skills and insights. Its purpose is to promote the exchange of ideas between library staff in the U.S. and the U.K. The deadline for applications is August 1, 1990. For more information and a list of libraries approved for affiliation, please call: (202) 6867878 , or write: CIES, 3400 International Drive, N.W., Suite M-500, Washington, DC 20008. 